\title{
EFFECT OF ADVANCED CHILLING METHODS ON LIPID DAMAGE DURING SARDINE (Sardina pilchardus) STORAGE
}

\author{
Vanesa Losada ${ }^{1}$, Jorge Barros-Velázquez ${ }^{2}$, José M. Gallardo ${ }^{1}$ and \\ Santiago P. Aubourg ${ }^{1, *}$
}

\footnotetext{
${ }^{1}$ Department of Seafood Chemistry; Institute for Marine Research (CSIC), C/ Eduardo Cabello 6, 36208-Vigo (Galicia, Spain)

${ }^{2}$ Department of Analytical Chemistry, Nutrition and Food Science, School of Veterinary Sciences, University of Santiago de Compostela, 27002-Lugo (Galicia, Spain)

*Correspondent: Fax: +34 986 292762; e-mail: saubourg@iim.csic.es
}

Running title: Lipid damage during sardine chilling

Keywords: Sardine, chilled storage, slurry ice, ozone, lipid hydrolysis and oxidation, quality, shelf-life 


\section{SUMMARY}

Slurry ice is a biphasic system consisting of small spherical ice crystals surrounded by seawater at subzero temperature. Its effect on lipid damage (hydrolysis and oxidation) was evaluated during the chilled storage of a fatty fish species (sardine, Sardina pilchardus). Slurry ice treatment was checked alone and in combination with ozone and compared to traditional flake icing during a 22 days storage. Different lipid damage indices (free fatty acids, FFA; peroxide value, PV; thiobarbituric acid index, TBA-i; fluorescent compounds, FR) were checked and compared to sensory assessment and nucleotide degradation ( $\mathrm{K}$ value). According to lipid hydrolysis (FFA) and oxidation (PV and FR) developments, slurry ice showed an inhibitory effect $(p<0.05)$ on lipid damage during storage, as well as an inhibition of nucleotide autolytic degradation. Ozonised slurry ice did not provide differences $(p>0.05)$ from slurry ice alone when considering lipid hydrolysis, nucleotide degradation and some lipid oxidation indices (PV and FR), although, a higher $(\mathrm{p}<0.05)$ TBA-i was observed at day 22 of storage when compared to flake ice and slurry ice treatments; however, a lower $(p<0.05)$ fluorescence development was observed for fish treated under ozonised slurry ice when compared to traditionally iced fish. Sensory assessment showed a higher shelf-life time for fish samples treated under ozonised slurry ice than for their counterparts under slurry ice (15 days versus 12 days), while flake icing lead to a far shorter shelf-life time (5 days). According to sensory and biochemical (lipid matter and nucleotide) analysis, employment of slurry ice is highly recommended for damage inhibition and quality retention in a fatty fish species such as sardine. Ozonised slurry ice is also recommended since, a longer shelf-life was obtained and a pro-oxidant effect of ozone on sardine lipids was not proved. 


\section{INTRODUCTION}

Slurry ice has been reported to be a promising technique for the preservation of aquatic food products in an ice-water suspension at subzero temperature [1, 2]. It has shown to provide several advantages towards flake ice such as: lower temperature, faster chilling, lower physical damage to product and better heat exchange power. Although the theoretical advantages of slurry ice are well known, few empirical data reporting the potential practical advantages derived from the use of slurry ice for the storage of marine species are available. Thus, good results were obtained with slurry ice for storage of albacore tuna [3] and hake [4], and as a slaughter method for seabream (Sparus aurata) [5]. For crustacean species, practical advantages were obtained in the case of Australian prawns [6] and shrimp [7].

Ozone is a powerful antimicrobial agent that is suitable for application in food in the gaseous and aqueous states leading to significant increases in sensory quality and shelf-life of fish [8, 9]. Molecular ozone or its decomposition products inactivate microorganisms rapidly by reacting with intracellular enzymes, nucleic material and other components. In spite of its advantages as a food additive, the pro-oxidant behaviour of ozone on fish food constituents has been studied scarcely. Some previous research has shown a detrimental effect on phospholipid classes, polyunsaturated fatty acids and membrane proteins $[10,11]$.

Marine lipids are constituted by highly unsaturated fatty acids [12] that are known to be very prawn to lipid oxidation $[13,14]$. During chilled storage of fatty fish species, a strong effect of lipid damage has been detected on fish quality loss [15-17]. Previously mentioned slurry ice applications [3-7] have shown damage inhibition concerning sensory assessment, microbiological activity, nucleotide degradation and 
volatile amine formation. However, the effect of slurry ice on lipid matter has hardly been elucidated till now.

The present work focuses on the evolution of lipid damage (hydrolysis and oxidation) as affected by storage in slurry ice, either alone or combined with ozone. For it, a fatty fish species (sardine, Sardina pilchardus) was chosen and stored up to 22 days. Results are compared with traditional flake icing. Lipid damage assessment is complemented by sensory analysis and nucleotide degradation determination.

\section{MATERIALS AND METHODS}

\section{$\underline{\text { 2.1. Refrigeration systems }}$}

Slurry ice was prepared using a FLO-ICE prototype (Kinarca S.A.U., Vigo, Spain). The composition of the slurry ice binary mixture was $40 \%$ ice and $60 \%$ water, prepared from filtered seawater (salinity: 3.3\%). The temperature of the slurry ice mixture was $-1.5^{\circ} \mathrm{C}$. The injection of ozone in the slurry ice mixture was accomplished with a prototype provided by Cosemar Ozono (Madrid, Spain), the redox potential being adjusted to $660 \mathrm{mV}(0.17 \mathrm{mg}$ ozone/L). In this batch, the ozone concentration was monitored by readings of the redox potential in the liquid phase. Flake ice was prepared with an Icematic F100 Compact device (Castelmac SPA, Castelfranco, Italy).

The fish specimens were surrounded by either ozonised slurry ice, slurry ice, or flake ice at a fish:ice ratio of 1:1, and stored for up to 22 days in a refrigerated room at $2^{\circ} \mathrm{C}$. When required, the ice mixtures were renewed. 


\subsection{Fish material, processing and sampling}

Fresh sardine (Sardina pilchardus) specimens were caught (November, 2003) near the Galician Atlantic coast and transported to the laboratory ten hours after catching. The fish specimens were not headed nor gutted and were directly placed in ozonised slurry ice, slurry ice or flake ice in an isothermal room at $2^{\circ} \mathrm{C}$. The length of the specimens was in the $16-21 \mathrm{~cm}$ range and average weight was $150 \mathrm{~g}$. Three different groups were used for each icing treatment and studied separately along the whole experimental period. Samples were taken for analysis on days $0,2,5,8,12,15$, 19 and 22. Once fish specimens had been subjected to sensory analyses, the white muscle was separated and employed for biochemical analyses. All analyses were performed in triplicate.

\subsection{Sensory analysis}

Sensory analysis was conducted by a sensory panel consisting of five experienced judges, according to guidelines concerning fresh and refrigerated fish [18]. Four categories were ranked: highest quality (E), good quality (A), fair quality (B) and unacceptable quality (C). Sensory assessment of the fish included the following parameters: skin, external odour, gills, consistency and flesh odour.

\subsection{Composition analyses}

Water content was determined by the difference between the weight of fresh homogenised muscle (1-2 g) and the weight recorded after $24 \mathrm{~h}$ at $105{ }^{\circ} \mathrm{C}$. Results are expressed as g water/100 g muscle. Lipids were extracted by the Bligh and Dyer [19] method. Quantification results are expressed as g lipid/100 g muscle. NaCl content in fish muscle was calculated from the amount of chlorine by boiling in $\mathrm{HNO}_{3}$ with excess 
of $\mathrm{AgNO}_{3}$, followed by titration with $\mathrm{NH}_{4} \mathrm{SCN}$ [20]. Results are expressed as $\mathrm{g}$ $\mathrm{NaCl} / 100$ g muscle.

\subsection{Lipid damage assessment}

Free fatty acid (FFA) content was determined by the Lowry and Tinsley [21] method based on complex formation with cupric acetate-pyridine. Results are expressed as g FFA/100 g lipids.

The peroxide value (PV) was determined according to the ferric thiocyanate method [22]. Results are expressed as milliequivalents of oxygen/kg lipids.

The thiobarbituric acid index (TBA-i) was determined according to Vyncke [23]. Results are expressed as mg malondialdehyde/kg fish sample.

Formation of fluorescent compounds was determined with a Perkin Elmer LS 3B fluorimeter by measurements at 393/463 nm and 327/415 nm as previously described $[16,24]$. The relative fluorescence $(R F)$ was calculated as follows: $R F=F / F_{s t}$, where $F$ is the fluorescence measured at each excitation/emission maximum, and $F_{s t}$ is the fluorescence intensity of a quinine sulphate solution $\left(1 \mu \mathrm{g} / \mathrm{mL}\right.$ in $\left.0.05 \mathrm{M} \mathrm{H}_{2} \mathrm{SO}_{4}\right)$ at the corresponding wavelength. The fluorescence ratio (FR) was calculated as the ratio between the two $R F$ values: $F R=R F_{393 / 463} n m / R F_{327 / 415} \mathrm{~nm}$. The $\mathrm{FR}$ value was determined in the aqueous phase resulting from the lipid extraction [19].

\subsection{Nucleotide degradation analysis}

Analysis of the nucleotide autolytic degradation was carried out by the method of Ryder [25]. The $\mathrm{K}$ value was calculated according to the following concentration ratio: $\mathrm{K}$ value $=100 \mathrm{x}$ (hypoxanthine + inosine $) /$ (adenosine triphosphate + adenosine 
diphosphate + adenosine monophosphate + inosine monophosphate + inosine + hypoxanthine).

\subsection{Statistical analyses}

Biochemical data corresponding to the three chilling methods were subjected to one-way analysis of variance to assess significant $(\mathrm{p}<0.05)$ differences among treatments [26]. Correlation analysis with time of the different parameters was studied; for sensory values, the Spearman test was employed [26]. The SPSS 11.5 software for Windows (SPSS Inc., Chicago, Il, USA) was also used to explore the statistical significance of the results obtained, including multivariate contrasts and multiple comparisons by the Scheffé and Tuckey tests; a confidence interval at the 95\% level was used in all cases.

\section{RESULTS AND DISCUSSION}

\subsection{Composition analyses}

Water contents of the different white muscle samples were in the range $71.0-$ $73.5 \%$, while the lipid content ranged between 3.0 and $5.5 \%$. Differences in both constituents may be explained as a result of fish-to-fish variations and not derived from chilling conditions and storage time.

The presence of $\mathrm{NaCl}$ in the chilling medium has lead in both slurry ice treatments to a progressive increase of $\mathrm{NaCl}$ content in fish white muscle (Figure 1). This increase was stronger in the presence of ozone than without it $(p<0.05)$. It is concluded that ozone renders fish samples to be more permeable to $\mathrm{NaCl}$ diffusion. 
Both slurry ice treatments provided a good correlation value between $\mathrm{NaCl}$ content and chilled time $\left(r^{2}=0.98\right.$ in both cases) (Table 1$)$. Fish samples treated under traditional flake ice did not show differences $(\mathrm{p}>0.05)$ in $\mathrm{NaCl}$ content during the experiment.

\subsection{Lipid hydrolysis}

Lipid hydrolysis was determined according to the FFA assessment (Table 2). FFA content of the raw material $(0.24 \pm 0.08)$ was rather similar to those of other fatty fish species (tuna, mackerel) [15, 27] and lower than those of lean fish (haddock, cod, Atlantic pomfret) $[24,28]$. Evolution of FFA content along storage in the three conditions did not provide good correlation values with time (Table 1). In the present experiment, no significant differences were obtained among the three treatments during the 0-15 days period. Then, a higher FFA content was observed for flake icing when compared to both slurry ice conditions. For this period, an inhibitory effect of slurry ice on lipid hydrolysis was concluded. No significant differences were obtained between both slurry ice conditions, so that no effect of ozone on lipid hydrolysis was denoted.

In addition to the temperature lowering produced by both slurry ice treatments, hydrolysis development may also be reduced as a result of the $\mathrm{NaCl}$ content increase (Figure 1) mentioned above, according to the inhibitory effect found for salt presence on FFA formation during fish processing [29-31].

The formation of FFA itself does not lead to nutritional losses. However, its examination was deemed to be important since it has been proved that the accumulation of FFA is related to some extent to lipid oxidation enhancement [32, 33] and to texture deterioration by interacting with proteins [34, 35]. 


\subsection{Lipid oxidation}

Primary lipid oxidation was followed by the PV (Table 2). Its assessment in both slurry ice conditions showed an increasing tendency with time, that was specially sharp at the end of the experiment (day 22). A different behaviour was observed for flake ice treatment, since an increase pattern was obtained till day 19, that was followed by a sharp decrease. This decrease can be explained as a result of peroxide breakdown. In the three treatments, a fair correlation value was obtained $\left(r^{2}=0.81-0.85\right)$ (Table 1). Comparison between flake and slurry icing conditions showed a higher PV for flake ice at days 5, 8 and 19. Ozonised slurry ice treatment did not show significant differences when compared to slurry ice, although higher mean values were obtained for ozonised slurry ice in most cases.

Secondary lipid oxidation was followed by the TBA-i (Table 2). Its assessment in all three conditions showed an increasing pattern, with some exceptions. The best correlation value was obtained for the flake ice treatment $\left(r^{2}=0.95\right)$ (Table 1). Differences between flake and both slurry icing conditions were obtained at day 8, being higher for the flake ice. Comparison of both slurry ice conditions showed a higher oxidation level at days 15 and 22 for the ozonised samples; a sharp increase of thiobarbituric acid reactive substance content was obtained at day 22 for fish samples treated under ozonised slurry ice.

Interaction compound formation [36, 37], also called tertiary oxidation compounds, produced during the chilled storage was studied by means of the fluorescence ratio [16, 24]. Till day 12, no differences were observed for the three treatments when compared to the raw material. After that time, a gradual increase was observed for flake iced fish, which showed higher FR values than both slurry ice treatments. Along the whole storage time, no differences $(\mathrm{p}>0.05)$ were obtained as a 
result of the ozone presence. All three treatments did not provide good correlation values between FR value and storage time (Table 1). The sharp increase found in flake ice samples for the 19-22 days period agrees with the no-variation period (days 15-22) observed for the TBA-i and with the sharp decrease obtained at day 22 for the PV. As a result of increased lipid oxidation in flake ice treated fish, primary and secondary oxidation compounds have interacted with nucleophilic compounds (aminated, namely) leading to fluorescent compound formation [38-40].

As mentioned above (Figure 1), both slurry ice treatments produced a $\mathrm{NaCl}$ content increase in fish muscle. Previous research [29, 31] has shown a pro-oxidant effect of salt on fish lipids. In the present study, comparison to flake iced fish led to a lower oxidation development for slurry ice treated samples, while a higher oxidation degree was not assessed for fish treated under ozonised slurry ice.

\subsection{Sensory analysis}

Sardine specimens stored in flake ice, maintained good quality (categories E and A) until day 2 (Table 3). After this time, sensory quality decreased and the batch exhibited unacceptable quality on day 8. In this batch, the limiting factors were the gills and the flesh odour, according to previously published information on flake ice chilled sardine $[41,42]$.

Sardine fish stored in slurry ice maintained good quality up to day 5 (Table 1). After this time, sensory quality decreased and on day 15 this batch was no longer acceptable. The appearance of the gills and eyes were the first parameters that limited fish acceptability. In a previous work related to slurry ice treatment of seabream (Sparus aurata) [5], eyes appearance was also reported to be the limiting factor. This 
enlargement of shelf-life found for the slurry ice treatment agrees with previous research on lean fish [4, 5] and crustacean [7] species.

Finally, fish treated under ozonised slurry ice maintained good quality up to day 8. After this time, sensory quality decreased and on day 19 this batch was no more acceptable. The appearance of the gills and eyes were again the first parameters that limited fish acceptability. This shelf-life enlargement agrees with previous research concerning ozone treatment on rockfish [8], catfish [9] and horse mackerel [43].

Both slurry ice conditions showed a very good correlation value between sensory assessment and chilled time $\left(r^{2}=0.96-0.98\right)$ (Table 1$)$. In the case of flake icing, a fair correlation value was observed $\left(r^{2}=0.88\right)$.

\subsection{Nucleotide analysis}

Nucleotide autolytic degradation was studied by means of the K value (Figure 2). All three conditions showed an increasing tendency along the storage, according to previous data on hypoxanthine and $\mathrm{K}$ values concerning traditional flake icing of sardine $[44,45]$. In the present study, very good correlation values were obtained in the three icing conditions $\left(\mathrm{r}^{2}=0.98-0.99\right)$ (Table 1$)$, according to previous research that considers the $\mathrm{K}$ value as a sound method for assessing quality changes during fish chilling [46]. In the present experiment, flake ice treatment showed significantly higher $(p<0.05)$ values than both slurry ice conditions; an inhibitory effect of slurry ice on nucleotide autolytic degradation is concluded. No significant differences were obtained between both slurry ice conditions, so that an inhibitory or enhancement effect of ozone on nucleotide degradation could not be assessed. 


\section{FINAL REMARKS}

The employment of slurry ice as a chilling technology has produced an inhibitory effect on lipid damage (hydrolysis and oxidation) related to quality loss during the chilled storage of a fatty fish species. These results agreed with the sensory assessment that led to longer shelf life times and good quality periods, and also with the nucleotide autolytic degradation analysis.

Ozonised slurry ice employment has provided an increase in shelf-life time and good quality period when compared to slurry ice alone. These increases are interesting and, since a pro-oxidant effect of ozone on lipid matter is not concluded, its employment is found beneficial for quality retention during a fatty fish species chilling.

Fish traders have employed chilled storage as a previous step to other technological treatments. The effect of previous chilling conditions (storage time, fishice ratio, room storage temperature) on the quality of frozen $[47,48]$ and canned $[49$, 50] fish has been demonstrated. In this sense, application of slurry ice technology (alone or in combination with ozone) could lead to higher quality fish products concerning the commercialisation of fatty fish products.

\section{ACKNOWLEDGEMENTS}

The authors wish to thank Kinarca S.A.U. for providing the slurry ice equipment and Cosemar Ozono for providing the ozone generator. This work was supported by the Secretaría Xeral de I+D from the Xunta de Galicia (Galicia, Spain) (Project PGIDTI02RMA18E). The authors also thank Mr. Marcos Trigo and Mr. José M. Antonio for their excellent technical assistance. 


\section{REFERENCES}

[1] L. Chapman: Making the grade. Ice slurries get top marks for quality products. Austral. Fish. 7 (1990) 16-19.

[2] K. Harada: How to handle Albacore. Austral. Fisher. February (1991) 28-30.

[3] R. Price, E. Melvin, J. Bell: Postmortem changes in chilled round, bled and dressed albacore. J. Food Sci. 56 (1991) 318-321.

[4] V. Losada, C. Piñeiro, J. Barros-Velázquez, S. Aubourg: Effect of slurry ice on chemical changes related to quality loss during European hake (Merluccius merluccius) chilled storage. Eur. Food Res. Technol. (2004). Accepted, in press.

[5] A. Huidobro, R. Mendes, M. L. Nunes: Slaughtering of gilthead seabream (Sparus aurata) in liquid ice: influence on fish quality. Eur. Food Res. Technol. 213 (2001) 267-272.

[6] H. Chinivasagam, H. Bremner, A. Wood, S. Nottingham: Volatile components associated with bacterial spoilage of tropical prawns. Int. J. Food Microb. 42 (1998) 45-55.

[7] A. Huidobro, M. López-Caballero, R. Mendes: Onboard processing of deepwater pink shrimp (Parapenaeus longirostris) with liquid ice: effect on quality. Eur. Food Res. Technol. 214 (2002) 469-475.

[8] J. Kötters, A. Pradur, B. Skura, H. Rosenthal, E. Black, J. Rodrigues-Lopez: Observations and experiments on extending shelf life of rockfish (Sebastes spp.) products with ozone. J. Appl. Icthiol. 13 (1997) 1-8.

[9] J. Kim, A. Yousef, S. Dave: Application of ozone for enhancing the microbiological safety and quality of foods: A review. J. Food Prot. 62 (1999) 1071-1087. 
[10] K. Fukunaga, T. Suzuki, K. Takama: Effect of ozone exposure on the compositions of gill and erythrocyte membrane lipids and proteins of Japanese charr (Salvelinus leucomaenis). Comp. Biochem. Physiol. B 100B (1991) 481-487.

[11] M. Takigi-Endo, K. Ono, K. Nakagawa, M. Yotsu-Yamashita, T. Miyazawa: Ozonation of PC in ethanol: Separation and identification of a novel ethoxyhydroperoxide. Lipids 37 (2002) 1007-1012.

[12] R. Ackman: Fatty acids. In: Marine biogenic lipids, fats and oils. Ed. R. Ackman, CRC Press, Boca Raton, FL (USA), Vol. 1, 1989, pp. 103-137.

[13] P. Harris, J. Tall: Rancidity in fish. In: Rancidity in foods. Eds. J. Allen, R. Hamilton, Chapman and Hall, London (UK) 1994, pp. 256-272.

[14] A. Kolakowska: Lipid oxidation in food systems. In: Chemical and functional properties of food lipids. Eds. Z. Sikorski, A. Kolakowska, CRC Press, London (UK) 2003, 133-165.

[15] K. Hwang, J. Regenstein: Lipid hydrolysis and oxidation of mackerel (Scomber scombrus) mince. J. Aquat. Food Prod. Technol. 5 (1996) 17-27.

[16] S. Aubourg, C. Sotelo, J. Gallardo: Quality assessment of sardines during storage by measurement of fluorescent compounds. J. Food Sci. 62 (1997) 295-299.

[17] I. Undeland, G. Hall, H. Lingnert: Lipid oxidation in fillets of herring (Clupea harengus) during ice storage. J. Agric. Food Chem. 47 (1999) 524-532.

[18] Council Regulation. Off. J. Eur. Comm. 19 February No. C 84 (1990) p. 69.

[19] E. Bligh, W. Dyer: A rapid method of total extraction and purification. Can. J. Biochem. Physiol. 37 (1959) 911-917.

[20] AOAC: Official methods of analysis of the Association of Analytical Chemistry. $15^{\text {th }}$ ed., 1990, p. 870. 
[21] R. Lowry, I. Tinsley: Rapid colorimetric determination of free fatty acids. J. Am. Oil Chem. Soc. 53 (1976) 470-472.

[22] R. Chapman, J. McKay: The estimation of peroxides in fats and oils by the ferric thiocyanate method. J. Am. Oil Chem. Soc. 26 (1949) 360-363.

[23] W. Vyncke: Direct determination of the thiobarbituric acid value in trichloroacetic acid extracts of fish as a measure of oxidative rancidity. Fette Seifen Anstrichm. 72 (1970) 1084-1087.

[24] S. Aubourg, I. Medina: Influence of storage time and temperature on lipid deterioration during cod (Gadus morhua) and haddock (Melanogrammus aeglefinus) frozen storage. J. Sci. Food Agric. 79 (1999) 1943-1948.

[25] J. Ryder: Determination of adenosine triphosphate and its breakdown products in fish muscle by high performance liquid chromatography. J. Agric. Food Chem. 33 (1985) 678-680.

[26] Statsoft: Statistica for Macintosh. Statsoft and its licensors, Tulsa, Oklahoma (USA) 1994.

[27] J. Gallardo, S. Aubourg, R. Pérez-Martín: Lipid classes and their fatty acids at different loci of albacore (Thunnus alalunga): Effects of precooking. J. Agric. Food Chem. 37 (1989) 1060-1064.

[28] F. Pérez-Alonso, C. Arias, S. Aubourg: Lipid deterioration during chilled storage of Atlantic pomfret (Brama brama). Eur. J. Lipid Sci. Technol. 105 (2003) 661667.

[29] S. Takiguchi: Effect of $\mathrm{NaCl}$ on the oxidation and hydrolysis of lipids in salted sardine fillets during storage. Nippon Suisan Gakkaishi 55 (1989) 1649-1654. 
[30] H. Refsgaard, P. Brockhoff, B. Jensen: Free polyunsaturated fatty acids cause taste deterioration of salmon during frozen storage. J. Agric. Food Chem. 48 (2000) 3280-3285.

[31] S. Aubourg, M. Ugliano: Effect of brine pre-treatment on lipid stability of frozen horse mackerel (Trachurus trachurus). Eur. Food Res Technol. 215 (2002) 9195.

[32] K. Miyashita, T. Takagi: Study on the oxidative rate and prooxidant activity of free fatty acids. J. Am. Oil Chem. Soc. 63 (1986) 1380-1384.

[33] H. Yoshida, I. Kondo, G. Kajimoto: Participation of free fatty acids in the oxidation of purified soybean oil during microwave heating. J. Am. Oil Chem. Soc. 69 (1992) 1136-1140.

[34] I. Mackie: The effects of freezing on flesh proteins. Food Rev. Int. 9 (1993) 575610.

[35] Z. Sikorski, A. Kolakowska: Changes in protein in frozen stored fish. In: Seafood proteins. Eds. Z. Sikorski, B. Sun Pan, F. Shahidi, Chapman and Hall, New York (USA) 1994, pp. 99-112.

[36] J. Pokorný: Browning from lipid-protein interactions. Prog. Food Nutr. Sci. 5 (1981) 421-428.

[37] N. Howell: Interaction of proteins with small molecules. In: Ingredient InteractionsEffects on Food Quality. Ed. A. Gaonkar, Marcel Dekker, New York (USA) 1995, pp. 269-289.

[38] K. Kikugawa, M. Верpu: Involvement of lipid oxidation products in the formation of fluorescent and cross-linked proteins. Chem. Phys. Lipids 44 (1987) 277-297. 
[39] K. Hasegawa, Y. Endo, K. Fujimoto: Oxidative deterioration in dried fish model systems assessed by solid sample fluorescence spectrophotometry. J. Food Sci. 57 (1992) 1123-1126.

[40] S. Aubourg: Review: Recent advances in assessment of marine lipid oxidation by using fluorescence. J. Am. Oil Chem. Soc. 76 (1999) 409-419.

[41] A. El Marrakchi, N. Bouchrit, N. Bennour, A. Hamama, H. Tagafit: Sensory, chemical and microbiological assessments of Moroccan sardines (Sardina pilchardus) stored in ice. J. Food Prot. 53 (1990) 600-605.

[42] L. Ababouch, L. Souibri, K. Rhaliby, O. Ouahdi, M. Battal, F. Busta: Quality changes in sardines (Sardina pilchardus) stored in ice and at ambient temperature. Food Microbiol. 13 (1996) 123-132.

[43] M. da Silva, P. Gibbs, R. Kirby: Sensorial and microbial effects of gaseous ozone on fresh scad (Trachurus trachurus). J. Appl. Microbiol. 84 (1998) 802-810.

[44] S. Ehira, H. Uchiyawa, K. Kakuda: Partial freezing as a means of keeping freshness of sardine. Bull. Tokai Reg. Fish. Lab. 114 (1984) 103-109.

[45] M. L. Nunes, I. Batista, R. Morao de Campos: Physical, chemical and sensory analysis of sardine (Sardina pilchardus) stored in ice. J. Sci. Food Agric. 59 (1992) 37-43.

[46] G. Olafsdóttir, E. Martinsdóttir, J. Oehlenschläger, P. Dalgaard, B. Jensen, I. Undeland, I. Mackie, G. Henehan, J. Nielsen, H. Nilsen: Methods to evaluate fish freshness in research and industry. Trends Food Sci. Technol. 8 (1997) 258265.

[47] I. Undeland, H. Lingnert: Lipid oxidation in fillets of herring (Clupea harengus) during frozen storage. Influence of prefreezing storage. J. Agric. Food Chem. 47 (1999) 2075-2081. 
[48] S. Aubourg, I. Lehmann, J. Gallardo: Effect of previous chilled storage on rancidity development in frozen horse mackerel (Trachurus trachurus). J. Sci. Food Agric. 82 (2002) 1764-1771.

[49] B. Slabyj, R. True: Effect of preprocess holding on the quality of canned Maine sardines. J. Food Sci. 43 (1978) 1172-1176.

[50] S. Aubourg, I. Medina: Quality differences assessment in canned sardine (Sardina pilchardus) by detection of fluorescent compounds. J. Agric. Food Chem. 45 (1997) 3617-3621. 


\section{FIGURE LEGENDS}

Figure 1: $\mathrm{NaCl}$ content assessment* in sardine muscle that was kept chilled under different conditions.

Figure 2: K value assessment* in sardine muscle that was kept chilled under different conditions. 


\section{TABLE 1}

Correlation values* between the storage time and different parameters measured during sardine chilled storage under different conditions**

\begin{tabular}{|c|c|c|c|}
\hline Parameter & \multicolumn{3}{|c|}{ Chilled treatment } \\
\hline & Flake Ice & Slurry Ice & $\begin{array}{c}\text { Ozonised Slurry } \\
\text { Ice }\end{array}$ \\
\hline $\mathrm{NaCl}$ & 0.40 & 0.98 & 0.98 \\
\hline $\mathrm{FFA}$ & $0.51)^{\mathrm{b}}$ & & 0.67 \\
& 0.40 & 0.75 & $(0.74)^{\mathrm{b}}$ \\
\hline $\mathrm{PV}$ & $0.53)^{\mathrm{b}}$ & $(0.78)^{\mathrm{b}}$ & 0.81 \\
& 0.85 & 0.81 & $(0.85)^{\mathrm{a}}$ \\
\hline TBA-i & 0.95 & $0.83)^{\mathrm{a}}$ & 0.84 \\
& & & $(0.85)^{\mathrm{a}}$ \\
\hline FR & 0.01 & -0.31 & -0.10 \\
& $(0.27)^{\mathrm{a}}$ & $(-0.43)$ & $0.37)^{\mathrm{b}}$ \\
\hline Sensory acceptance & 0.88 & 0.96 & 0.99 \\
\hline K value & 0.98 & 0.99 & \\
\hline
\end{tabular}

* Linear correlations are expressed in all cases. Non-linear fittings (exponential ${ }^{\mathrm{a}}$ and logarithmic ${ }^{\mathrm{b}}$ ) are expressed in brackets when the coefficients are higher than the linear ones.

** Lipid damage abbreviations: FFA (free fatty acids), PV (peroxide value), TBA-i (thiobarbituric acid index) and FR (fluorescence ratio). 


\section{TABLE 3}

Sensory acceptance* during sardine storage under different chilled conditions

\begin{tabular}{|c|c|c|c|c|c|c|c|}
\hline Icing & \multicolumn{7}{|c|}{ Storage Time (days) } \\
\cline { 2 - 8 } Conditions & $\mathbf{2}$ & $\mathbf{5}$ & $\mathbf{8}$ & $\mathbf{1 2}$ & $\mathbf{1 5}$ & $\mathbf{1 9}$ & $\mathbf{2 2}$ \\
\hline Flake Ice & $\mathrm{A}$ & $\mathrm{B}$ & $\mathrm{C}$ & $\mathrm{C}$ & $\mathrm{C}$ & $\mathrm{C}$ & $\mathrm{C}$ \\
\hline Slurry Ice & $\mathrm{E}$ & $\mathrm{A}$ & $\mathrm{B}$ & $\mathrm{B}$ & $\mathrm{C}$ & $\mathrm{C}$ & $\mathrm{C}$ \\
\hline $\begin{array}{c}\text { Ozonised } \\
\text { Slurry Ice }\end{array}$ & $\mathrm{E}$ & $\mathrm{A}$ & $\mathrm{A}$ & $\mathrm{B}$ & $\mathrm{B}$ & $\mathrm{C}$ & $\mathrm{C}$ \\
\hline
\end{tabular}

*Freshness categories: E (excellent), A (good), B (fair) and C (unacceptable). Raw fish was category E. 


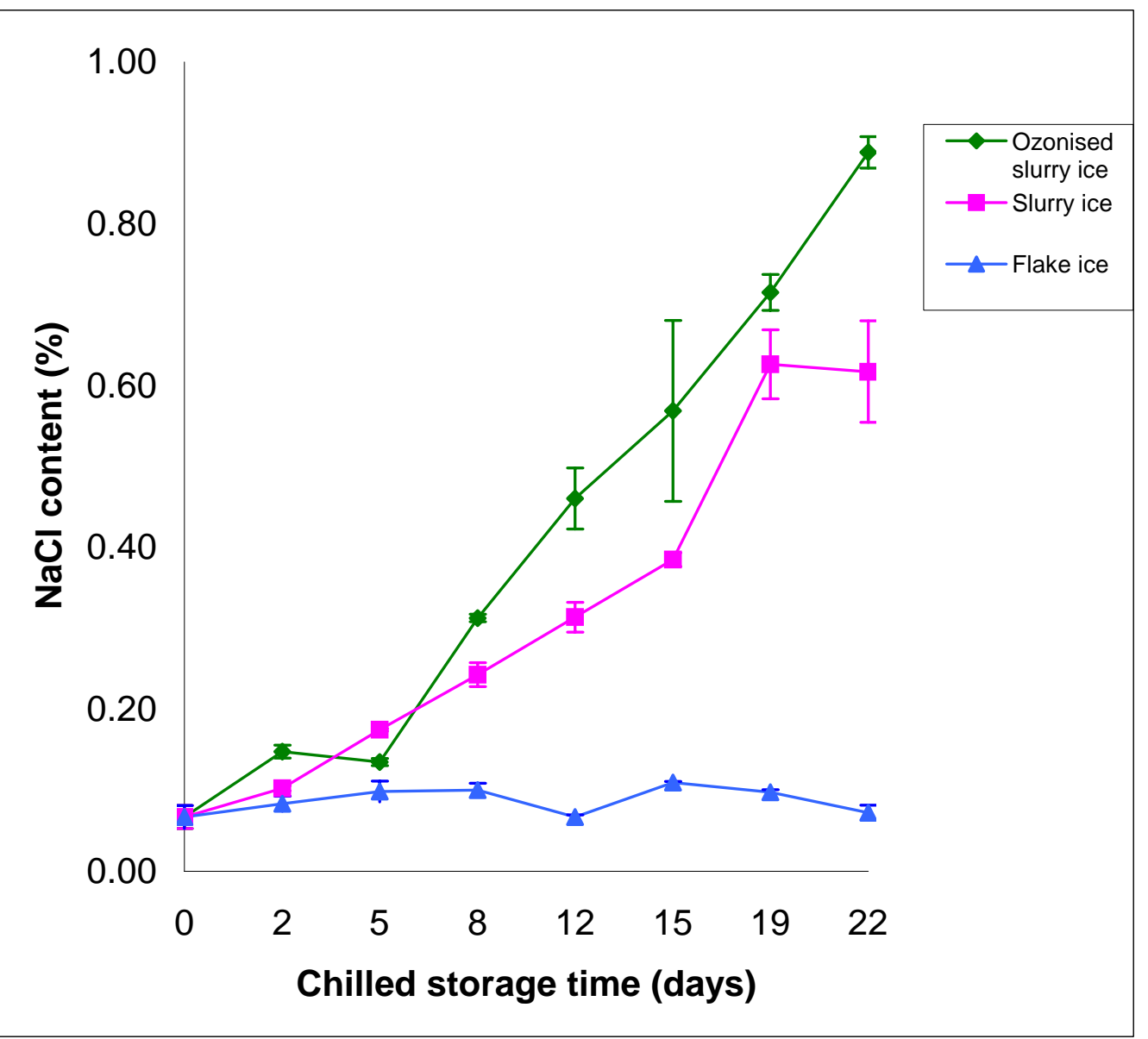




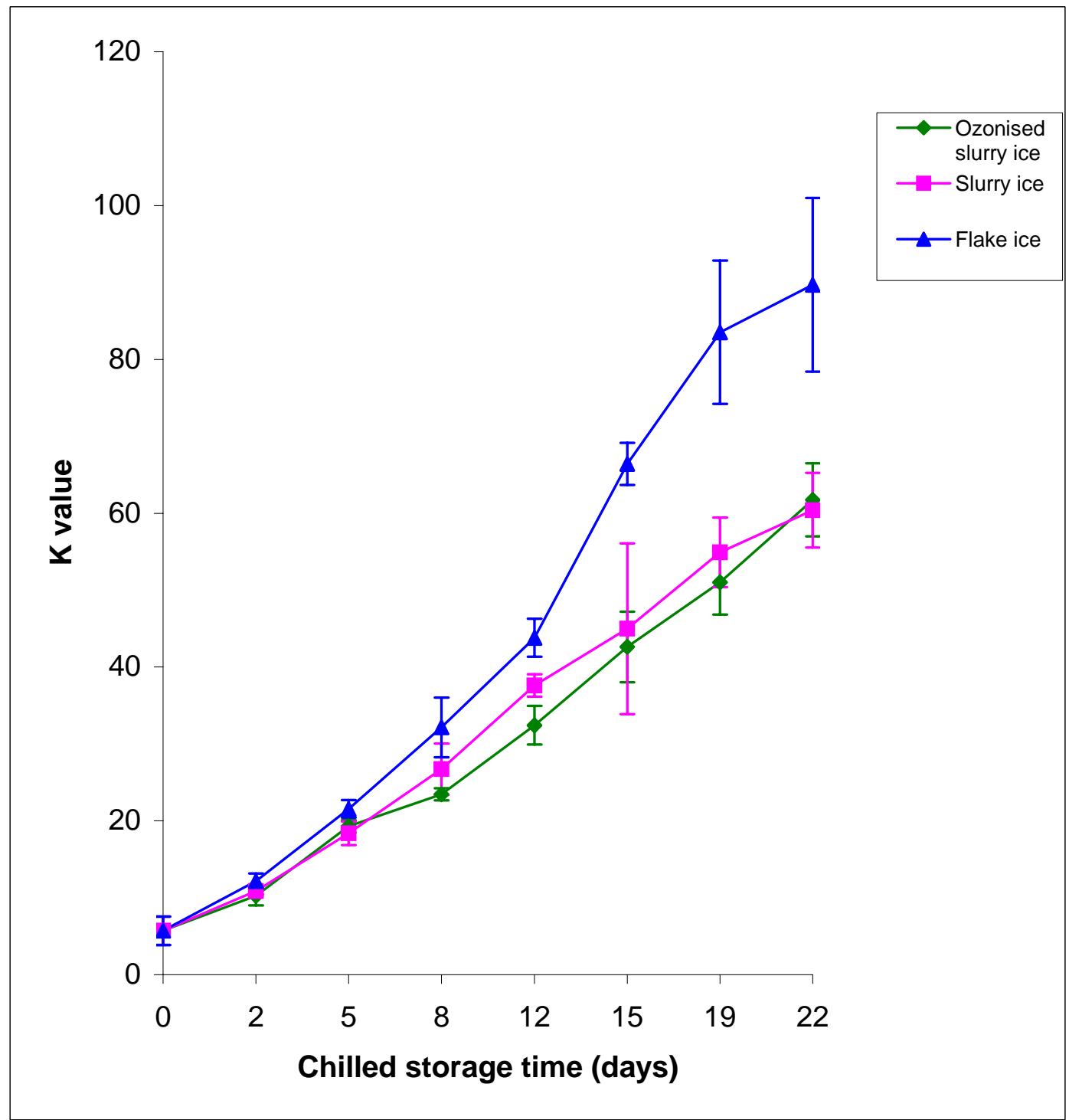




\section{TABLE 2}

Lipid damage assessment* during sardine storage under different chilled conditions**

\begin{tabular}{|c|c|c|c|c|c|c|c|c|c|c|c|c|}
\hline \multirow{2}{*}{$\begin{array}{c}\text { Chilled } \\
\text { Storage } \\
\text { Time } \\
\end{array}$} & \multicolumn{3}{|c|}{ FFA } & \multicolumn{3}{|c|}{ PV } & \multicolumn{3}{|c|}{ TBA-i } & \multicolumn{3}{|c|}{ FR } \\
\hline & FI & SI & OSI & FI & SI & OSI & FI & SI & OSI & FI & SI & OSI \\
\hline 2 & $\begin{array}{c}0.36 \\
(0.05)\end{array}$ & $\begin{array}{c}0.34 \\
(0.05)\end{array}$ & $\begin{array}{c}0.41 \\
(0.04)\end{array}$ & $\begin{array}{c}2.08 \\
(0.37)\end{array}$ & $\begin{array}{c}1.89 \\
(2.01)\end{array}$ & $\begin{array}{c}3.28 \\
(1.72)\end{array}$ & $\begin{array}{c}0.65 \\
(0.21)\end{array}$ & $\begin{array}{c}0.57 \\
(0.09)\end{array}$ & $\begin{array}{c}0.63 \\
(0.32)\end{array}$ & $\begin{array}{c}0.06 \\
(0.01)\end{array}$ & $\begin{array}{c}0.09 \\
(0.01)\end{array}$ & $\begin{array}{c}0.09 \\
(0.02)\end{array}$ \\
\hline 5 & $\begin{array}{c}0.49 \mathrm{ab} \\
(0.15)\end{array}$ & $\begin{array}{c}0.38 \mathrm{a} \\
(0.02)\end{array}$ & $\begin{array}{c}0.47 \mathrm{~b} \\
(0.04)\end{array}$ & $\begin{array}{c}7.20 \mathrm{~b} \\
(2.57)\end{array}$ & $\begin{array}{c}3.60 \mathrm{a} \\
(1.44)\end{array}$ & $\begin{array}{c}5.18 \mathrm{ab} \\
(1.11)\end{array}$ & $\begin{array}{c}0.99 \\
(0.23) \\
\end{array}$ & $\begin{array}{c}1.14 \\
(0.28) \\
\end{array}$ & $\begin{array}{c}1.38 \\
(0.42) \\
\end{array}$ & $\begin{array}{c}0.05 \\
(0.02) \\
\end{array}$ & $\begin{array}{c}0.06 \\
(0.01) \\
\end{array}$ & $\begin{array}{c}0.06 \\
(0.01) \\
\end{array}$ \\
\hline 8 & $\begin{array}{c}0.41 \\
(0.17)\end{array}$ & $\begin{array}{c}0.55 \\
(0.15)\end{array}$ & $\begin{array}{c}0.62 \\
(0.10)\end{array}$ & $\begin{array}{c}13.38 \mathrm{~b} \\
(3.94)\end{array}$ & $\begin{array}{l}4.02 \mathrm{a} \\
(1.34)\end{array}$ & $\begin{array}{c}4.26 \mathrm{a} \\
(2.44)\end{array}$ & $\begin{array}{c}1.83 \mathrm{~b} \\
(0.20)\end{array}$ & $\begin{array}{c}0.89 \text { a } \\
(0.26)\end{array}$ & $\begin{array}{l}1.12 \mathrm{a} \\
(0.42)\end{array}$ & $\begin{array}{c}0.07 \\
(0.03)\end{array}$ & $\begin{array}{c}0.07 \\
(0.02)\end{array}$ & $\begin{array}{c}0.06 \\
(0.02)\end{array}$ \\
\hline 12 & $\begin{array}{c}0.49 \\
(0.04)\end{array}$ & $\begin{array}{c}0.53 \\
(0.01) \\
\end{array}$ & $\begin{array}{c}0.50 \\
(0.11) \\
\end{array}$ & $\begin{array}{l}10.73 \\
(1.20) \\
\end{array}$ & $\begin{array}{l}11.29 \\
(1.85) \\
\end{array}$ & $\begin{array}{l}10.74 \\
(2.77) \\
\end{array}$ & $\begin{array}{c}1.84 \\
(0.32) \\
\end{array}$ & $\begin{array}{c}1.61 \\
(0.18) \\
\end{array}$ & $\begin{array}{c}1.71 \\
(0.29) \\
\end{array}$ & $\begin{array}{c}0.08 \\
(0.02) \\
\end{array}$ & $\begin{array}{c}0.09 \\
(0.04) \\
\end{array}$ & $\begin{array}{c}0.08 \\
(0.03) \\
\end{array}$ \\
\hline 15 & $\begin{array}{c}0.40 \\
(0.06)\end{array}$ & $\begin{array}{c}0.49 \\
(0.09)\end{array}$ & $\begin{array}{c}0.47 \\
(0.10)\end{array}$ & $\begin{array}{l}19.66 \\
(9.14)\end{array}$ & $\begin{array}{l}15.71 \\
(6.61)\end{array}$ & $\begin{array}{l}16.57 \\
(5.26)\end{array}$ & $\begin{array}{c}2.59 \mathrm{ab} \\
(0.72)\end{array}$ & $\begin{array}{l}1.86 \text { a } \\
(0.12)\end{array}$ & $\begin{array}{c}3.14 b \\
(0.19)\end{array}$ & $\begin{array}{c}0.22 \mathrm{~b} \\
(0.08)\end{array}$ & $\begin{array}{c}0.09 \mathrm{a} \\
(0.02)\end{array}$ & $\begin{array}{c}0.10 \mathrm{a} \\
(0.03)\end{array}$ \\
\hline 19 & $\begin{array}{c}0.89 \mathrm{~b} \\
(0.06)\end{array}$ & $\begin{array}{c}0.56 \mathrm{a} \\
(0.20)\end{array}$ & $\begin{array}{c}0.54 \mathrm{a} \\
(0.17)\end{array}$ & $\begin{array}{c}26.83 \mathrm{~b} \\
(3.00)\end{array}$ & $\begin{array}{c}13.37 \mathrm{a} \\
(7.18)\end{array}$ & $\begin{array}{c}17.66 \mathrm{ab} \\
(9.63)\end{array}$ & $\begin{array}{c}2.66 \\
(0.04) \\
\end{array}$ & $\begin{array}{c}2.22 \\
(0.91)\end{array}$ & $\begin{array}{c}2.12 \\
(0.38)\end{array}$ & $\begin{array}{c}0.58 \mathrm{~b} \\
(0.05)\end{array}$ & $\begin{array}{c}0.10 \mathrm{a} \\
(003)\end{array}$ & $\begin{array}{c}0.11 \mathrm{a} \\
(0.03)\end{array}$ \\
\hline 22 & $\begin{array}{c}1.70 \mathrm{~b} \\
(0.69)\end{array}$ & $\begin{array}{c}0.64 \text { a } \\
(0.17)\end{array}$ & $\begin{array}{c}0.68 \text { a } \\
(0.10)\end{array}$ & $\begin{array}{c}12.49 \mathrm{a} \\
(5.43)\end{array}$ & $\begin{array}{c}35.35 \mathrm{ab} \\
(12.17)\end{array}$ & $\begin{array}{c}49.23 \mathrm{~b} \\
(10.75)\end{array}$ & $\begin{array}{c}2.55 \mathrm{a} \\
(0.30)\end{array}$ & $\begin{array}{c}2.07 \mathrm{a} \\
(0.35)\end{array}$ & $\begin{array}{c}5.73 \text { b } \\
(0.29)\end{array}$ & $\begin{array}{c}0.91 \text { b } \\
(0.39)\end{array}$ & $\begin{array}{c}0.18 \mathrm{a} \\
(0.08)\end{array}$ & $\begin{array}{c}0.16 \mathrm{a} \\
(0.05)\end{array}$ \\
\hline
\end{tabular}

* For each damage index, mean values $(n=3)$ in the same row followed by different letters are significantly different $(\mathrm{p}<0.05)$. Standard deviations are indicated in parentheses.

** Chilled treatments: FI (flake ice), SI (slurry ice) and OSI (ozonised slurry ice). Abbreviations of lipid damage indices as expressed in Table 1. 
